\title{
La memoria histórica y los usos de la imagen
}

\author{
Alberto Del Castillo Troncoso*
}

El interés de este artículo es el de reflexionar sobre el estatus de las fotografías documentales, así como el uso y la circulación de las mismas con otros documentos para la investigación histórica, como los testimonios orales.

El punto de partida obligado consiste en recordar que la tradición occidental ha privilegiado a lo largo de la historia las manifestaciones del lenguaje escrito por encima de las representaciones icónicas y con eso ha conformado la cultura logocéntrica que ha regido nuestra percepción de la realidad.

En este contexto, lo que queremos enfatizar en este espacio es la posibilidad de trabajar con las imágenes consideradas no como un mero reflejo o copia de la realidad, sino como una construcción, esto es, como un artefacto cultural que implica la necesidad de leerlas e interpretarlas en función de contextos concretos. Todo ello para poder llegar en un momento dado a elaborar una interpretación iconológica, como planteaba en sus investigaciones Panofsky, o adentrarnos en "el ojo de la época", como deseaba el historiador Michael Baxandall (1972).

De esta manera, nos referiremos a las imágenes como vestigios y no como fuentes, ya que consideramos que los primeros se adecuan más a la complejidad de un concepto como construcción cultural, mientras que las segundas constituyen una metáfora muy gastada - la simple idea de fuente nos remite a una premisa de pureza - que implica una visión del acto de historiar como una simple búsqueda pasiva del saber, donde supuestamente se encontraría depositada la verdad, algo muy lejano a la perspectiva crítica de las investigaciones actuales.

* Investigador del Instituto Mora-Conacyt, México. 
Por todo lo anterior, nos interesan las imágenes no como un simple reflejo de la realidad, sino como el punto de partida para la recreación de universos simbólicos que dotan de sentido e inteligibilidad al quehacer humano en todas sus expresiones, al crear una serie de imaginarios colectivos que legitiman a una sociedad en un momento determinado. En este sentido, el estudio de la disputa simbólica por las imágenes constituye uno de los capítulos centrales de una historia cultural interesada en leer las maneras en que las sociedades se construyen a sí mismas, como veremos en los siguientes apartados.

\section{Imagen e historia}

Los historiadores han utilizado las imágenes para sus trabajos desde hace muchos años. Sin embargo, en la mayor parte de los casos lo han hecho con un sentido convencional, según el cual la imagen solo ilustraría los textos escritos. En la década de los sesenta del siglo pasado se produjo una renovación historiográfica de gran calado que modificó las premisas y los alcances de la historia social y cultural e incorporó nuevos enfoques y temáticas, tales como la historia de la vida cotidiana, la cultura material, el cuerpo, la sexualidad, la criminalidad y la locura, entre otros tópicos que habían mantenido una presencia marginal en los catálogos de la producción histórica.

Esta renovación obligó a re-pensar el uso de las imágenes y a considerarlas como códigos culturales, susceptibles de ser leídos e interpretados en función de una hermenéutica particular y de contextos históricos concretos. Un ejemplo de este tipo de revalorizaciones lo constituye la investigación de Philipe Ariès (1987) sobre la historia de la infancia en el Antiguo Régimen, que partió de la tesis fundamental que sostenía que esta etapa era un producto de la modernidad occidental y que en etapas anteriores como la Edad Media no se desarrolló un espacio cultural para reflexionar en torno al concepto de niñez.

La documentación básica aportada por el investigador francés se remitía a la cultura visual europea de la época, según la cual los niños no existían en sí mismos, sino que aparecían representados como adultos pequeños. A medio siglo de distancia ha corrido mucha tinta alrededor de estos planteamientos y se han matizado muchas de las tesis y argumentos de Ariès. Sin embargo, queda fuera de toda duda la importancia de esta investigación y su papel en las siguientes décadas como referencia para el resto de los historiadores al 
tratar estos asuntos, por ejemplo, en la explicación acerca de la manera en que ciertas categorías biológicas son en realidad construcciones sociales. ${ }^{1}$

Se trata de un ejemplo paradigmático que nos muestra de que manera la incorporación de las imágenes como vestigios documentales desempeñó un papel estratégico en este cambio de puntos de vista que modificó la visión de los historiadores en la segunda mitad del siglo pasado. En el caso concreto de México, las imágenes y representaciones infantiles adquirieron una notoriedad visible a principios del siglo pasado. (Foto 1 ).

Si atendemos al caso de la fotografía nos vamos dar cuenta de que la revalorización de las imágenes también ha cambiado el mapa historiográfico en las últimas décadas. En el caso de México, este cambio es visible a partir de la década de los ochenta, cuando una generación de investigadores procedentes de distintas disciplinas sociales comenzó a desarrollar una

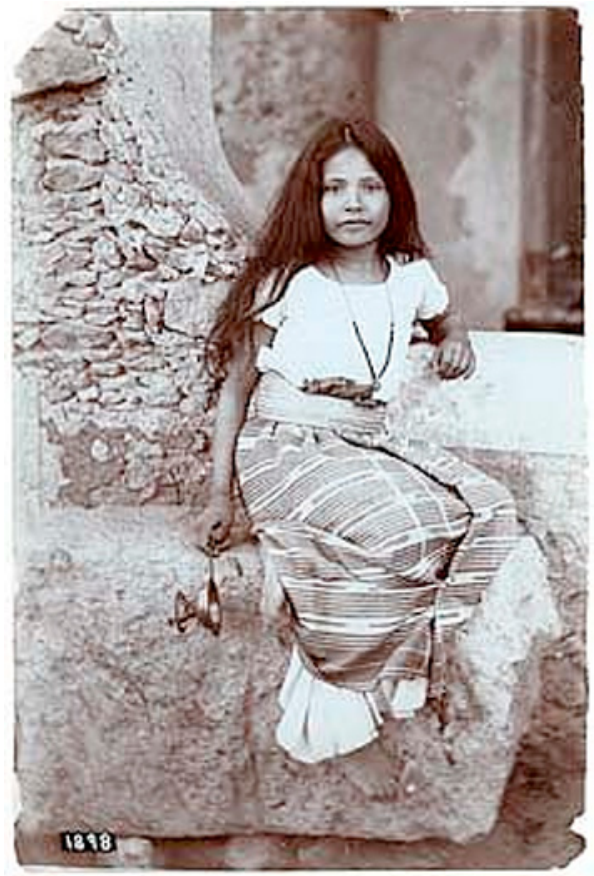

Foto 1. Niña adolescente. Charles B.

Waite, 1908 (Archivo General de la Nación). vasta aportación al campo de la historia política, social y cultural, que abarcó desde la recuperación y clasificación de todo tipo de archivos fotográficos y documentales hasta la apertura de nuevas discusiones metodológicas y hermenéuticas en torno a los documentos, pasando por la generación de información y planteamientos en torno a la comprensión de personajes, períodos $\mathrm{y}$ problemáticas históricas concretas.

La lectura e interpretación de las imágenes de los viajerosantropólogos de la segunda mitad del siglo XIX y su influencia en la reflexión de un pensamiento $\mathrm{y}$ una visión sobre los indígenas, el surgimiento de una cultura visual mexicana en los últimos dos siglos,

1 La investigación clásica del autor es Philippe Ariès (1987). Un balance de su recepción y una reflexión sobre el caso mexicano puede verse en: Alberto del Castillo (2006). 
las distintas versiones sobre la revolución mexicana, con el liderazgo de sus caudillos y la irrupción de nuevos actores sociales que modificaron la realidad del país, así como la reinvención de la nación misma, a través de la creación de uno de los imaginarios colectivos más poderosos de América Latina en el siglo XX y la generación de un fotoperiodismo creativo y vital en las décadas posteriores, son solo algunos de los tópicos y problemáticas que ha encarado esta nueva historia basada en evidencias documentales de carácter visual y que abarcan desde las litografías, los grabados, las caricaturas y las fotografías hasta la pintura y el cine documental y de ficción. ${ }^{2}$ (Foto 2 ).

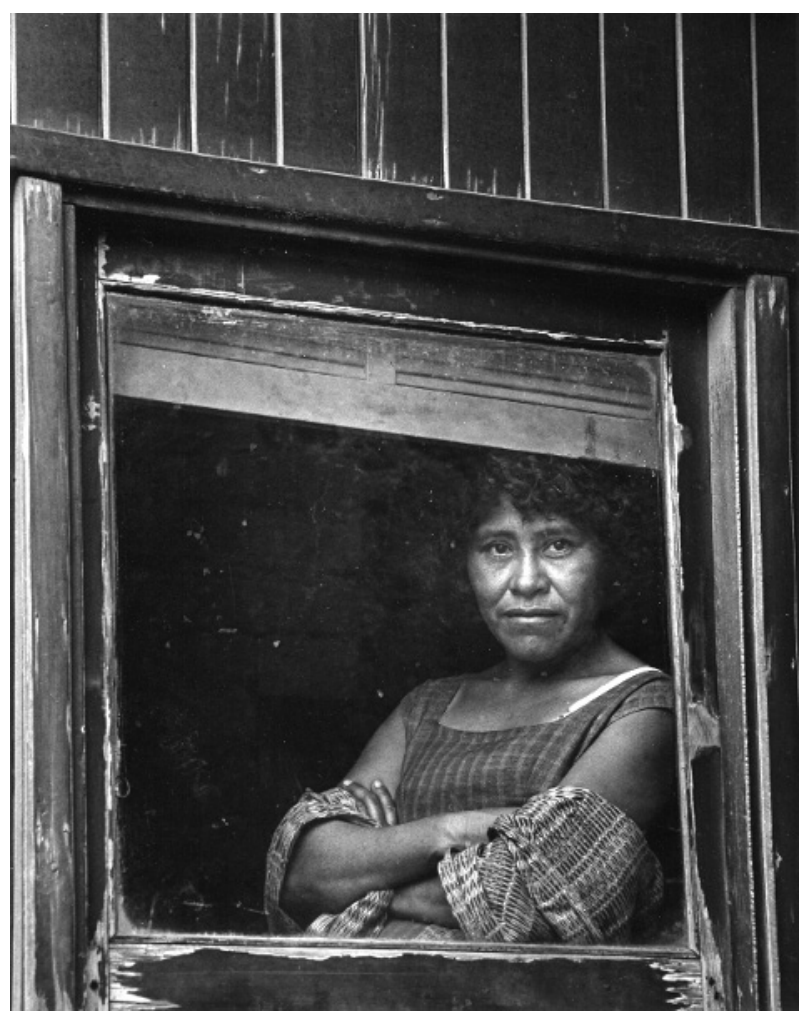

Foto 2. Retrato de mujer en un vagón de segunda clase, México. Rodrigo Moya, 1966 (Archivo Fotográfico Rodrigo Moya).

2 Una lectura global, rigurosa y documentada de algunas de las lecturas más destacadas en torno a una historia social de la fotografía en México puede consultarse en Emma García (2005). 


\section{La circulación de las imágenes}

A continuación revisaremos un caso concreto que da cuenta del enriquecimiento de una problemática histórica a partir de la aportación de la lectura de las imágenes y su confrontación con los testimonios orales.

El episodio que queremos comentar se refiere al movimiento estudiantil de 1968, el cual es considerado en la actualidad como un punto de inflexión central para el estudio de la historia contemporánea de México.

Este movimiento surgió a finales del mes de julio de aquel año como una respuesta de los estudiantes del Instituto Politécnico Nacional y la Universidad Nacional Autónoma Nacional de México en contra de la represión policíaca y

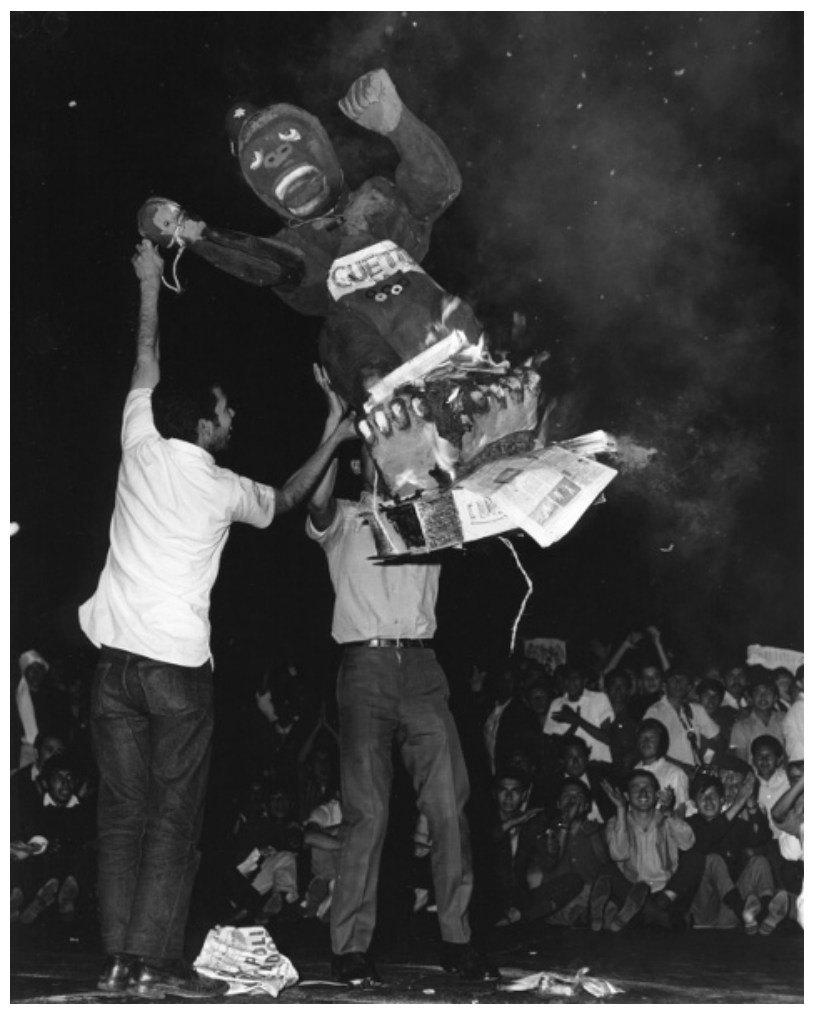

Foto 3. Estudiantes queman un gorila de papel maché que representa al Jefe de la Policía, México. Rodrigo Moya, 13 de agosto de 1968 (Archivo Fotográfico Rodrigo Moya). 
militar del gobierno. En los siguientes dos meses, cientos de miles de jóvenes marcharon por las calles y reivindicaron la necesidad de un estado derecho en un país gobernado por un régimen de partido de estado. Fue un movimiento ágil y contestatario, que renovó las formas de protesta pública en el país y que fue violentamente reprimido por el Estado la tarde del 2 de octubre en la Plaza de las Tres Culturas en el barrio de Tlatelolco, en el norte de la ciudad de México, exactamente diez días antes del inicio de los XIX juegos olímpicos.

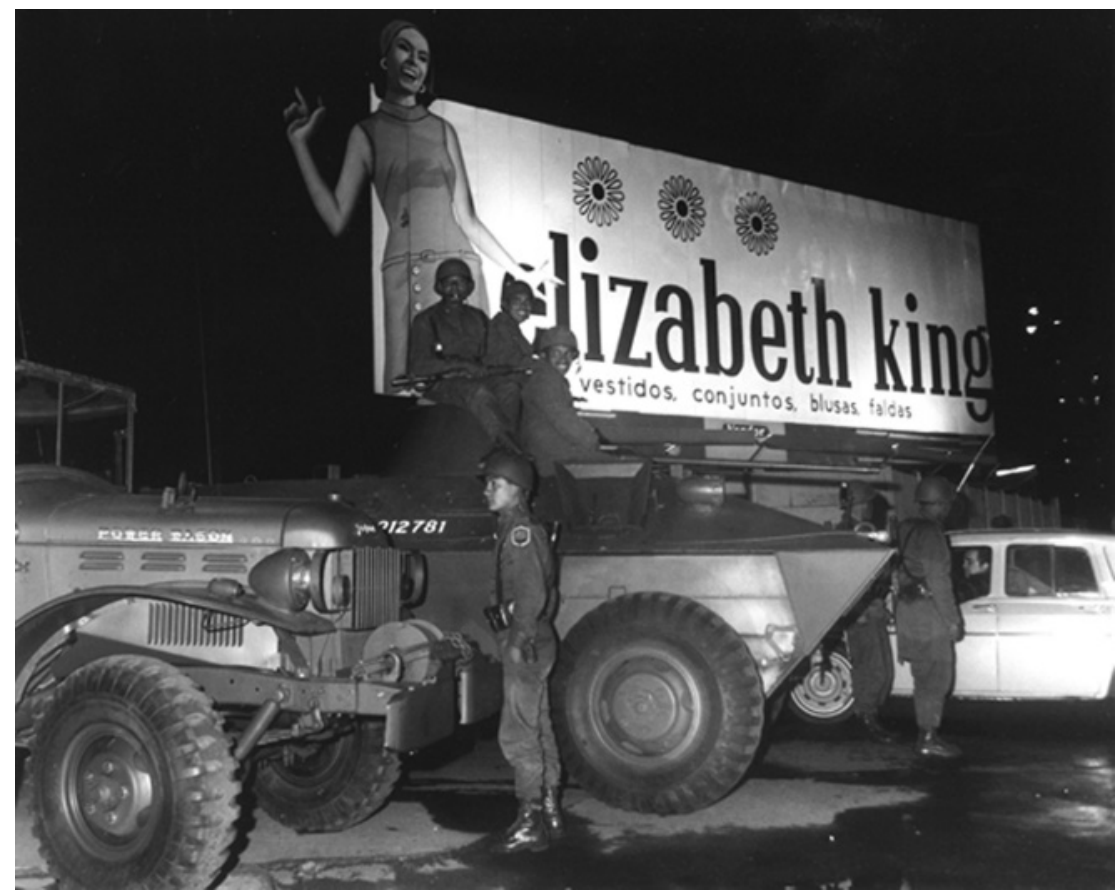

Foto 4. Soldados del ejército en los alrededores de Ciudad Universitaria, México. Rodrigo Moya, 18 de septiembre de 1968 (Archivo Fotográfico Rodrigo Moya).

A cuarenta años se ha construído en aquella plaza en Tlatelolco un museo conmemorativo del movimiento estudiantil por parte de la UNAM, el cual ha recibido el nombre de Memorial del 68.

Los elementos claves de la puesta en escena fueron el rescate de nuevos testimonios orales y la presentación de una síntesis fotográfica compuesta 
por imágenes publicadas en su momento en la prensa. Todo ello conforma un sitio de la memoria que condensa distintas visiones en torno a los hechos al tiempo que proporciona referencias y puntos de partida para la lectura de las nuevas generaciones, en la medida en que puede considerarse a la memoria no sólo como la conservación de ideas previamente retenidas, sino sobre todo, como la construcción simbólica y elaboración de sentidos del pasado. ${ }^{3}$

Los testimonios de cerca de sesenta personas, entre los que se encuentran los principales exlíderes estudiantiles, así como diversos políticos, intelectuales, artistas, escritores y analistas de distintas tendencias, se entrecruzan en monitores y otros espacios audiovisuales y se contextualizan a través de la presentación de secuencias fotográficas que dan contenido a cada uno de los episodios más relevantes del $68 .^{4}$

Esta valorización del testimonio de los protagonistas solo puede entenderse a partir de la renovación de la historia cultural y social de las últimas décadas, la cual enfatiza la importancia de los sujetos como actores sociales. A su vez, forma parte del llamado "giro subjetivo" estudiado por Beatriz Sarlo (2005).

En el año 2008, con motivo del aniversario número 40 del movimiento estudiantil, varios autores inauguramos una nueva exposición en el Memorial, titulada "Miradas en torno al 68", la cual agregó distintos testimonios orales y fotográficos desde puntos de vista diferentes, no contemplados en la exposición original. Distintos investigadores elaboramos una reflexión sobre el mundo de la literatura, la música, el cine y las artes plásticas, con lo que se concretó una nueva puesta museográfica basada en el universo de la cultura. Una de sus aportaciones consistió en la realización de entrevistas a siete destacados fotógrafos de la época con las selección de algunas de sus imágenes más importantes, en su mayoría no publicadas hasta este momento. ${ }^{5}$

3 "La memoria es una dimensión que atañe tanto a lo privado, es decir, a procesos y modalidades estrictamente individuales y subjetivos de vinculación con el pasado (y por ende con el presente y el futuro), como a la dimensión pública, colectiva e intersubjetiva. Más aún, la noción de memoria nos permite trazar un puente, una articulación entre lo íntimo y lo colectivo, ya que invariablemente los relatos y sentidos construídos colectivamente influyen en las memorias individuales." (Franco; Levín, 2007, p. 31).

4 La curaduría de esta exposición y la realización de las entrevistas corrió a cargo del investigador Álvaro Vázquez mantecón.

5 La exposición "Miradas en torno al 68" tuvo lugar en el Memorial DEL 68 del Centro Cultural Universitario Tlatelolco de la UNAM de septiembre del 2008 a febrero del 2009. El autor de este articulo se encargo del tema de la fotografía, mientras que los investigadores Ricardo Pérez Montfort, Álvaro Vázquez, Greco Sotelo y Pilar García se ocuparon de la música, el cine, la literatura y las artes plásticas. 
El tema es importante y tiene que ver con los usos de estos testimonios e imágenes en el contexto de esta puesta en escena museográfica, como parte de una contribución a la formación de espacios que funcionan como disparadores de la memoria colectiva.

El Memorial constituye una importante referencia para el público capitalino y se ha posicionado como uno de los museos con mayor audiencia juvenil. La propuesta de reflexionar sobre el 68 a partir de la convergencia de testimonios orales y fotografías permite no solo el enriquecimiento de la historiografía sobre un tema central para el pasado reciente de México, sino la construcción de puentes y vínculos con generaciones que no vivieron el conflicto, pero que tienen familiares y amigos que fueron protagonistas de los hechos. En esta medida, la demanda social generada en torno al 68 mexicano en todos estos años permite revisar la perspectiva del historiador como parte de un proceso cívico que acompaña la reivindicación de un importante sector de ciudadanos. ${ }^{6}$

Las imágenes fotográficas cumplieron en el 68 un papel muy destacado, ante la cerrazón casi absoluta de los distintos medios de comunicación, como la radio y la televisión, y ocuparon un lugar simbólico de primera importancia, por lo que fueron utilizadas y manipuladas desde las posturas políticas y los lugares sociales más diversos.

Este imaginario generado en las páginas de los medios impresos circuló en forma amplia a nivel nacional e internacional, permeó las conciencias y el pensamiento de distintos sectores sociales y proporcionó referentes visuales claves para la construcción de una memoria colectiva que se alimentaría de algunas de estas fotografías convertidas en iconos a lo largo de varios años.

Estas lecturas resultan de gran importancia para comprender los distintos ángulos de percepción con que fue registrado el movimiento y la manera en que se fue construyendo un imaginario colectivo que influyó en vastos sectores sociales y que se fue reciclando a lo largo de cuatro décadas hasta convertirse en una referencia importante de la memoria colectiva. Cuando el movimiento comenzó a ser recuperado por las distintas facciones políticas a partir de la década de los setenta del siglo XX, la amplia cobertura de que

6 Este trabajo fue discutido en un seminario coordinado por el filósofo Andreas Huyssen en el Centro de Las Artes de San Luis Potosí en septiembre del 2009. Agradezco la invitación de las organizadoras de este foro interdisciplinario, las investigadoras María del Carmen y Mónica Szurmuck. Para una reflexión más amplia del autor en torno al ejercicio de la memoria y la política, véase: Andreas Huyssen (2002, p. 34-37). 
fue objeto se fue decantando en unos cuantos iconos emblemáticos que se divulgaron una y otra vez en los distintos aniversarios y conmemoraciones del conflicto estudiantil como parte de la narrativa oficial de los sucesos.

Esta reducción empobreció notablemente la riqueza y la heterogeneidad del movimiento y lo redujo a la exhibición de unas cuantas imágenes convertidas en estereotipos. Tomemos el ejemplo de la que constituye quizá la imagen más famosa e influyente del 68 , esto es, la secuencia del fotógrafo Jesús Díaz que muestra a la periodista Oriana Fallaci arrastrándose por el piso del Edificio "Chihuahua" el 2 de octubre, la cual fue publicada en México por la revista Life en Español y le dio la vuelta al mundo a través de la agencia UPI.
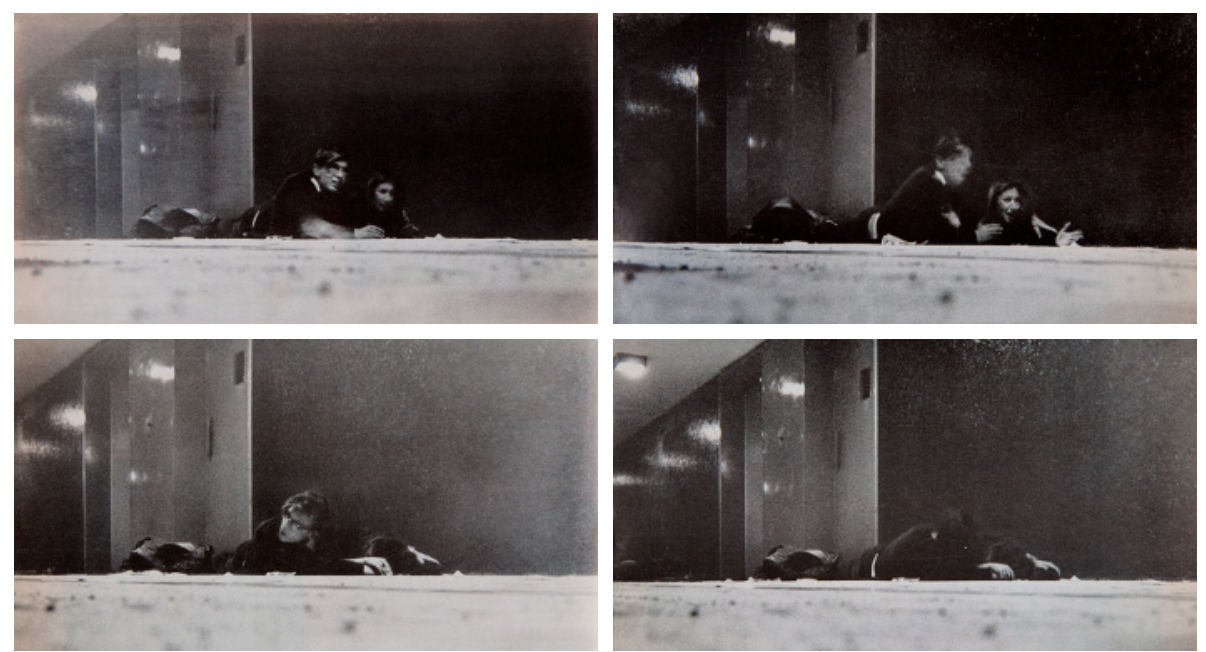

Fotos 5, 6, 7, y 8 . Secuencia de la agresión contra la periodista Oriana Fallaci y su asistente en Tlatelolco, México, 2 de octubre de 1968. Revista Life (Colección Particular.)

El ejemplo es significativo y vale la pena detenerse en él. A diez días de la inauguración de los juegos, una parte importante de prensa extranjera ya cubría la fuente olímpica y buscaba familiarizarse con los usos y costumbres del país anfitrión. La violencia gubernamental desplegada en CU y el Politécnico en la segunda quincena de septiembre llamó la atención de cualquier observador no comprometido con el discurso oficial, que aseguraba tener el control de la situación. La celebración de un mitin en Tlatelolco el 2 de octubre convocó a un sector importante de esta prensa. Como botón de muestra, 
tomemos el caso de Brasil, el país latinoamericano que registró uno de los movimientos estudiantiles más poderosos en aquel año, el cual sacudió las raíces del régimen militar sudamericano durante varios meses, lo que configuró para la prensa de aquella nación un espacio de reflexión muy significativa sobre lo que estaba ocurriendo en México.

El diario $O$ Globo publicó la secuencia de la Fallaci al día siguiente de la masacre, y en el editorial correspondiente explicó que la matanza de Tlatelolco representaba el fin del supuesto milagro "revolucionario" y "progresista" de México construido a lo largo de varias décadas, que había puesto a salvo a este país de las dictaduras militares. ${ }^{7}$

El titular señala: "Pánico y muerte en la batalla de México" y omite el nombre de la periodista. El contexto de la primera plana es muy revelador y se refiere al conflicto estudiantil en Sao Paulo, con saldo de un muerto. La prensa brasileña abrió así un interesante espacio de diálogo periodístico y visual entre las dos rebeliones estudiantiles más poderosas de la América Latina en aquel año.

La foto, leída como prueba documental de la violencia gubernamental, se complementaba con el testimonio de un periodista del diario brasileiro que había llegado unos días antes al país a cubrir las notas olímpicas y que asistió al mitin estudiantil aquella tarde, con tan buena puntería que se encontraba en el tercer piso del "Chihuahua” en el momento en el que se desató la balacera.

En su testimonio, el periodista informa que fue testigo de la golpiza contra los estudiantes en Tlatelolco desencadenada por un agente gubernamental mexicano, quién al llegar a él cambio la mueca agresiva por una sonrisa al enterarse de su nacionalidad brasilera. Los insultos fueron cambiados de inmediato por una amena plática en la que el agente disertó sobre la belleza de las brasileñas y la grandeza del futbolista Edson Arantes do Nascimento, "Pelé, de quién el policía aseguraba que había nacido en Río de Janeiro.

Al final el periodista fue puesto en libertad y se escabulló lo más rápido que pudo entre las calles aledañas a la Plaza de las Tres Culturas. Terminó su artículo en $O$ Globo confesando a sus lectores que aunque sabía que Pelé había nacido en Minas Gerais y no en Río, jamás pasó por su mente la idea de contradecir al psicópata con licencia para matar que por varios minutos el gobierno del presidente Gustavo Díaz Ordaz le había puesto enfrente.

7 O Globo, 4 de octubre de 1968. 


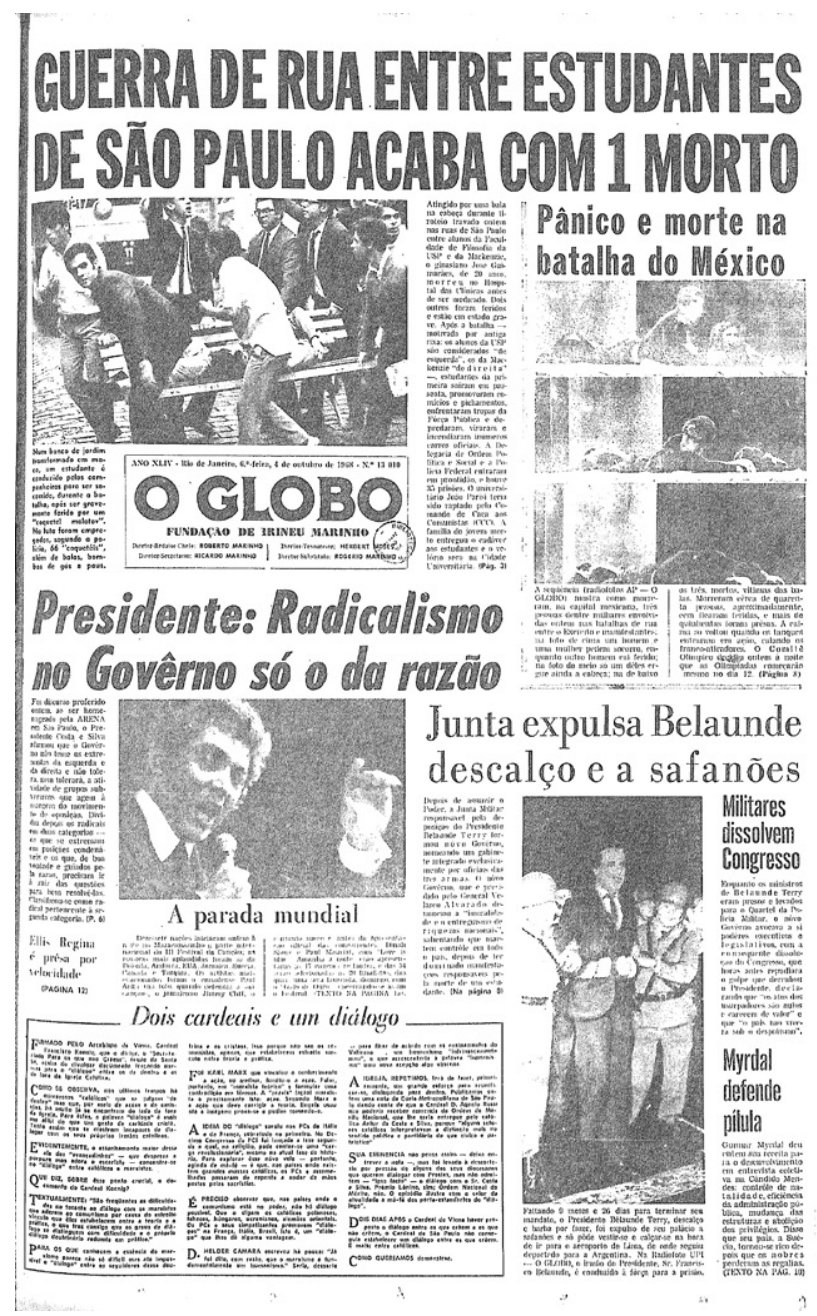

Foto 9. Portada del diario O Globo, Brasil, 4 de octubre de 1968 (Biblioteca Nacional, RJ).

Este caso ilustra la divulgación de una secuencia fotográfica que adquiere el valor de icono universal del movimiento y que sin embargo es leída de maneras muy distintas en diferentes contextos políticos y culturales. La existencia del movimiento estudiantil brasilero proporcionó un punto de referencia óptimo a aquella nación sudamericana para explorar los alcances y los límites de la experiencia mexicana. 
Finalmente, consideramos que este tipo de trabajos contribuyen a generar una reflexión en torno a la construcción de estos sitios de la memoria en los que este tipo de documentación es leída y asimilada por grupos sociales más amplios, que en este caso proceden del sector juvenil que acude a los museos de la Universidad, la máxima casa de estudios del país.

\section{Reflexiones finales}

Una historia social y cultural de las imágenes en México contempla los cambios en la evolución tecnológica de los soportes materiales, así como en las implicaciones culturales de los cambios en la difusión y recepción, que, como es sabido, el significado de las imágenes se modifica en función de los contextos. Al mismo tiempo, dialoga con los puntos de vista y enfoques historiográficos predominantes para cada período histórico, para establecer las posibles aportaciones de la cultura visual a los distintos problemas planteados por los investigadores. Aún queda mucho por hacer al respecto. Sin embargo, los avances registrados en los últimos años en las distintas academias y centros de investigación permiten visualizar nuevos horizontes estéticos para una disciplina histórica mucho más creativa, que combine la lectura e interpretación de las imágenes con todo tipo de documentación oral y escrita.

Por lo que respecta al movimiento estudiantil de 1968, a cuarenta años de distancia, el tratamiento periodístico del 68 ha sufrido cambios espectaculares: la prensa controlada del gobierno que estigmatizó a los estudiantes como alborotadores al servicio de móviles comunistas ha sido desplazada por medios con una mayor independencia del poder político y el 68 ha sido reconocido como un episodio clave para la fundación de un régimen democrático en México, lo cual no lo exenta de otro tipo de usos y manipulaciones políticas.

La combinación de los testimonios orales desplegados por los fotógrafos cuarenta años después de los sucesos y el cotejo con algunas de sus imágenes constituye el punto de partida para nuestro análisis. Reconocemos las diferencias entre la historia, basada en una pretensión de veracidad, y la memoria, alineada hacia un posible horizonte de fidelidad. Sin embargo, retomando a Ricoeur (2000), apelaremos a su necesaria interdependencia y de esa manera intentaremos superar el papel simplista de una historia convencional empeñada en corregir los "errores" del recuerdo. 
El relato de los distintos fotógrafos debe leerse al pie de este tipo de contradicciones y paradojas. Las escenas que ayer fueron capturadas en contextos peligrosos y con un carácter contestatario o progubernamental -según hayan sido las coordenadas de trabajo de cada autor-, hoy son percibidas como parte del patrimonio documental que recrea un episodio cívico ejemplar.

En la actualidad y a contrapelo de posibles apologías y canonizaciones, el relato oral y gráfico de los profesionales de la lente aporta interesantes claroscuros para una comprensión más profunda de uno de los episodios más relevantes de la historia contemporánea latinoamericana.

La proliferación de detalles ilustrados por las escenas particulares de las imágenes fotográficas se opone a la representación generalizada y uniforme prevista por los lineamientos oficiales.

Podemos concluír entonces que la fotografía siempre estuvo ahí, y el tabú obligado acerca de la ausencia de imágenes del 68 es un lugar común que no resiste la prueba de la investigación documental. El problema en realidad consistió en que cada medio le construyó una contextualización distinta y en los años posteriores esa diversidad fue reducida a la publicación y la divulgación ad nauseam de unos cuantos íconos que simplificaron y empobrecieron un proceso bastante complejo.

En octubre de 1968 la clase política en su conjunto aplaudió el operativo gubernamental del 2 de octubre y la represión generalizada contra los estudiantes. Las cámaras de diputados y senadores apoyaron la masacre y los directores de los periódicos expresaron su apoyo incondicional al gobierno de Díaz Ordaz.

Cuarenta años después, el poder ejecutivo ha exaltado al 68 como un episodio "clave" para la democracia del país y el legislativo en pleno ha ordenado inscribir en letras de oro el movimiento estudiantil, como un homenaje a los protagonistas del mismo y su contribución a la democracia. Los antiguos "alborotadores" y "terroristas" quedaron convertidos en próceres y mártires fundadores de la democracia en México. Las coordenadas de lo políticamente correcto se alteraron drásticamente en unos cuantos años, incidiendo en la memoria colectiva de todos los actores sociales.

En este sentido, este tipo de propuestas representa un punto de referencia poco utilizado en la historia del fotoperiodismo en México y América Latina. El propósito de este texto ha sido poner en evidencia su utilidad, aunque también subrayar la necesidad de contextualizar los testimonios con 
otro tipo de documentos gráficos y escritos, toda vez que las imágenes y las palabras comparten una perspectiva ética construída desde la investigación. En palabras de Andreas Huyssen (2009, p. 15-16):

No hay memoria sin imágenes, no hay conocimiento sin posibilidad de ver, aún si las imágenes no pueden proporcionar un conocimiento total. Eso es algo que tienen en común con las palabras. Pero si fuera cierto que las imágenes se prestan al abuso y al engaño con más facilidad que el lenguaje verbal, sería más importante todavía insistir en una ética y una política de las imágenes, así como damos por sentado que hay una ética del habla y la lectura.

\section{Referencias}

ARIÉS, P. El niño y la vida familiar en el Antiguo Régimen. Madrid: Taurus, 1987.

BAXANDALL, M. Painting and experience in fifteenth century Italy: a primer in the social history of pictorial style. Oxford: Clarendon Press, 1972.

DEL CASTILLO, A. Conceptos, imágenes y representaciones de la niñez en la ciudad de México: 1880-1920. México: El Colegio de México/Instituto Mora, 2006.

FRANCO, M.; LEVÍN, F. (Comp.). Historia reciente: perspectivas y desafíos para un campo de construcción. Buenos Aires: Paidós, 2007.

GARCÍA, E. (Coord.). Imaginarios y fotografía en México: 1839-1970. Madrid: Lunwerg/ Conaculta, 2005.

HUYSSEN, A. En busca del futuro perdido: cultura y memoria en tiempos de globalización. México: Fondo de Cultura Económica, 2002. p. 34-37.

. Medios y memoria. In: FELD, C.; STITES MOR, J. El pasado que miramos: memoria e imagen ante la historia reciente. Buenos Aires: Paidós, 2009. p. 15-24.

RICOEUR, P. La memoria, la historia y el olvido. Buenos Aires: Fondo de Cultura Económica, 2000.

SARLO, B. Tiempo pasado. Buenos Aires: Sigo XXI, 2005. 
Resumo: Este artigo reflete em torno dos usos da imagem fotográfica e de sua vinculação com os testemunhos orais. Discute-se, particularmente, o caso do México e a recente criação de um museu sobre o movimento estudantil de 1968, no qual se tem usado as imagens e os testemunhos como ponto de partida para a criação de uma memória histórica para as novas gerações.

Palavras-chave: fotografia, memória, história, cidadão, repressão.

\section{Historical memory and the uses of imagery}

Abstract: This article reflects on the uses of the photographic image and its relationship to oral testimony. In particular, it is argued on the case of Mexico and the recent creation of a museum about the 1968 student movement in which images and testimonials have been used as a starting point for the creation of a historical memory for future generations.

Keywords: photography, memory, history, citizen, repression.

Recebido em 01/12/2010

Aprovado em 15/01/2011 